\title{
EFFECTS OF SANGUINARINE AND CHELERYTHRINE ON THE CELL CYCLE AND APOPTOSIS
}

\author{
Jana Malikova $^{\mathrm{a}}$, Adela Zdarilova ${ }^{\mathrm{b}^{*}}$, Alice Hlobilkova ${ }^{\mathrm{a}}$ \\ a Laboratory of Molecular Pathology and Institute of Pathology, Faculty of Medicine, Palacký University, Hnèvotínská 3, \\ 77515 Olomouc, Czech Republic \\ ${ }^{b}$ Institute of Medical Chemistry and Biochemistry, Faculty of Medicine, Palacký University, Hněvotínská 3, 77515 Olomouc, \\ Czech Republic \\ e-mail:alfa.baba@seznam.cz
}

Received: April 15, 2006; Accepted (with revisions): June 5, 2006

Key words: Quaternary benzo/c]phenanthridine alkaloids/Cytotoxicity/Apoptosis/Cancer/Cell signalling/Proliferation

OBJECTIVES: This review summarizes the involvement of sanguinarine and chelerythrine in cell cycle regulation and cell death in various cell lines. It is focused on their potential in the treatment of cancer.

METHODS: We conducted a search of PubMed, ScienceDirect and Medline for papers on the molecular mechanisms of the biological activity of sanguinarine and chelerythrine published mainly from 1995 to 2006.

RESULTS AND CONCLUSIONS: Our analysis of the published studies suggested that these alkaloids are not only good candidates for chemotherapeutic regimens but may also contribute to the development of successful immune therapies of some carcinomas due to their apoptotic potential. However, the complete signalling cascade in which sanguinarine and chelerythrine treatment induces apoptotic cell death is not yet understood. Overall, the results of recent studies suggest that sanguinarine and chelerythrine may be useful as agents in the management of cancer.

\section{INTRODUCTION}

Sanguinarine (SA) and chelerythrine (CHE), benzo[c]phenanthridine alkaloids (QBA), isolated from Sanguinaria Canadensis, Chelidonium majus, and Macleya cordata are known to exert a wide spectrum of biological activities, e.g. from antimicrobial, antifungal, anti-inflammatory, adrenolytic, sympatholytic and local anaesthetic to include cytotoxicity against various human normal and cancer cell lines ${ }^{1}$.

SA and other QBA-containing extracts exhibit a low acute oral toxicity (sanguinarine $\mathrm{LD}_{50}=1.7$, and $1.4 \mathrm{~g} / \mathrm{kg}$, resp.; rat). In subchronic studies, minor evidence of treatment-related toxicity of QBA (doses > $30 \mathrm{mg} / \mathrm{kg} /$ day; rat, monkey) has been reported ${ }^{2}$.

From the chemistry point of view, both alkaloids interconvert between the cationic vs. neutral form (i.e. hydroxide adduct or pseudobase). They penetrate the cell membrane in the form of nonpolar pseudobase ${ }^{3}$. The iminium bond, $\mathrm{C}_{6}=\mathrm{N}^{+}$in the cationic form is susceptible to nucleophilic attack and plays a key role in inhibition of SH-proteins ${ }^{4}$. The binding of SA and CHE with human serum albumin and L-cysteine is radically weaker at $\mathrm{pH} 5.0$ than at $\mathrm{pH}$ 7.4. This observation is the basis for the conclusion ${ }^{5}$ that the neutral form (pseudobase) of SA and CHE can interact with proteins, it is involved in the interactions with cellular biomacromolecules and may elicit a cytotoxic response ${ }^{6}$. SA and CHE forms in vitro DNA adducts via modification of the $\mathrm{C}_{(11)}=\mathrm{C}_{(12)}$ bond (calf thymus DNA, rat hepatic microsomes, NADPH, pH 7.4) detectable by ${ }^{32} \mathrm{P}$-postlabelling?
QBA fractions from $S$. canadensis (SANGUINARIA) and $M$. cordata (SANGUIRITRIN) are used in toothpastes and mouthwashes as antiplaque agents. SANGUIRITRIN is applied as a veterinary preparation for mastoiditis in cows $^{8}$. The QBA fraction from the part of M. cordata, containing SA and CHE is an active component of the preparation Sangrovit ${ }^{\circledR}$ as an additive to animal feeds.

Despite the above, SA, dihydrosanguinarine (DHSA) and $\mathrm{CHE}$ are considered to be the toxic components of the Argemone mexicana seed oil ${ }^{9}$. Several studies have suggested that singlet oxygen and hydroxyl radicals are involved in argemone oil toxicity. The role of QBA in the genesis of epidemic dropsy syndrome (A. mexicana poisoning) has not been explicated to date ${ }^{10}$, although SAmediated DNA damage in vitro ${ }^{11}$ (Fig. 1) and in vivo ${ }^{12-14}$ has been published. In studies focused on SA-mediated DNA damage in mice, the minimum genotoxically ef-

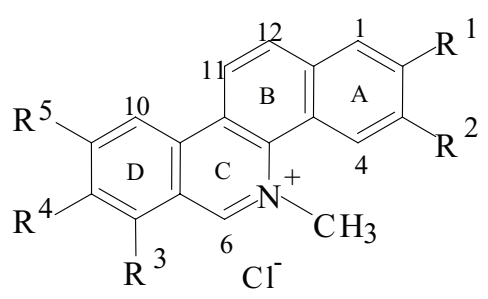

Sanguinarine (SA) Chelerythrine (CHE) $\mathrm{R}^{1}+\mathrm{R}^{2}=\mathrm{OCH}_{2} \mathrm{O}, \mathrm{R}^{3}+\mathrm{R}^{4}=\mathrm{OCH}_{2} \mathrm{O}, \mathrm{R}^{5}=\mathrm{H}$ $\mathrm{R}^{1}+\mathrm{R}^{2}=\mathrm{OCH}_{2} \mathrm{O}, \mathrm{R}^{3}=\mathrm{R}^{4}=\mathrm{OCH}_{3}, \mathrm{R}^{5}=\mathrm{H}$

Scheme 1. 


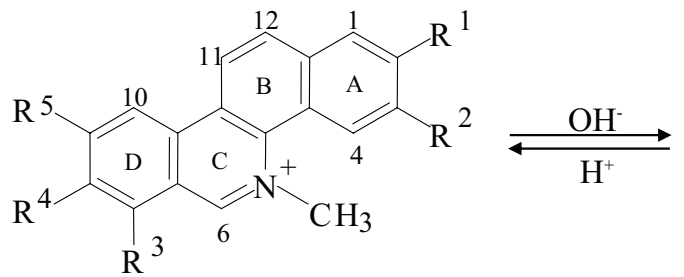

Sanguinarine $\quad \mathrm{R}^{1}+\mathrm{R}^{2}=\mathrm{OCH}_{2} \mathrm{O}, \mathrm{R}^{3}+\mathrm{R}^{4}=\mathrm{OCH}_{2} \mathrm{O}, \mathrm{R}^{5}=\mathrm{H}$ Chelerythrine $\quad \mathrm{R}^{1}+\mathrm{R}^{2}=\mathrm{OCH}_{2} \mathrm{O}, \mathrm{R}^{3}=\mathrm{R}^{4}=\mathrm{OCH}_{3}, \mathrm{R}^{5}=\mathrm{H}$

Scheme 2.

fective SA concentration ( $10 \mathrm{mg} / \mathrm{kg}$ body weight) was found after administration of a single intraperitoneal dose. The authors referred to benz $[c]$ acridine (3,4-benzacridine) as the principal toxic agent. This compound has been considered as the only metabolic product of SA biotransformation $^{15,16}$. Psotová et al. failed to confirm the formation of benz $[c]$ acridine as a metabolite of SA in rats after administration of a single dose of SA (10 mg. $\mathrm{kg}^{-1}$ ) (ref. ${ }^{17}$ ). DHSA was always found simultaneously with SA in the plasma and liver samples and its concentration was higher than SA. It is hypothesized that formation of DHSA is the first step in SA detoxification in rats. The same SA detoxification system was also found in a plant tissue culture (Eschscholzia californica) (ref. ${ }^{18}$ ). The reduction of SA to the DHSA form probably starts in the gastrointestinal tract by intestinal reductases ${ }^{19}$. After absorption of both substances, SA is further reduced by nonspecific cytosolic and microsomal reductases ${ }^{17}$. Vecera et al. reported that SA was distributed to all rat organs using $\left[{ }^{3} \mathrm{H}\right]-\mathrm{SA}$ and nearly $98 \%$ of orally administered SA was excreted in the faeces ${ }^{20}$.

This aside, the biological activities of SA and CHE are of particular interest in molecular biology and medicine. This review summarizes recent in vitro studies focused on the molecular mechanisms of SA and CHE effects on programmed cell death in a variety of human cell line models.

\section{Effects on programmed cell death}

In the last few years, clinical trials using plant-derived drugs for prevention and/or treatment of tumors have become increasingly widespread in cancer therapy. Search for novel agents designed to induce cell cycle arrest and apoptosis in cancer cells is being seriously pursued. QBAs affect eukaryotic cells in many ways and several cellular targets for their action have recently been established. The interaction of compounds with organelles and other intracellular targets depends on both cellular permeability and intracellular distribution ${ }^{21}$. In recent years, QBAs (especially SA) have gained increasing attention as potential agents in the treatment of cancer. SA and CHE have been reported to exert cell growth-inhibitory effects via the induction of apoptosis in a variety of cancer cells $\mathrm{s}^{22-25}$. The ability of tumor cells to evade apoptosis plays a significant role in their resistance to conventional therapeutic regimens ${ }^{26}$. Apoptosis is a term used to describe the terminal morphological and biochemical events seen in programmed cell death (PCD) (ref. ${ }^{27}$ ). Cell death as well as cell proliferation and differentiation are important for homeostasis. Cells undergoing PCD are characterized by morphological changes, including cellular shrinkage, plasma and nuclear membrane blebbing, organelle relocalization and compaction, nuclear DNA condensation with or without fragmentation, and hypersegmentation of nuclear chromatin of irregular size ${ }^{28-30}$. These hypersegmented nuclear structures may then bud from the rapidly blebbing cell surface to form "apoptotic bodies" 31 . Three mechanisms are known to be involved in the apoptotic process: (i) a receptor-ligand mediated mechanism, (ii) a mitochondrial pathway and (iii) a mechanism in which the endoplasmic reticulum plays a central role. All three mechanisms activate caspases which are responsible for the characteristic morphological changes observed during apoptosis ${ }^{32}$. Cell death marked by cellular swelling should be called oncosis. Necrosis is the cell death as a result of direct injury, usually beginning at the cell surface. Necrotic cells exhibit early lysis of the plasma membrane before any significant alterations in nuclear morphology. The surface features of necrosis are also very different from those of apoptosis. Necrotic cells swell and lyse, whereas apoptotic cells show intense cell surface zeiotic blebbing ${ }^{31}$. The genetic basis for apoptosis implies that cell death, like any other metabolic or developmental program, can be disrupted by mutation. In fact, defects in apoptotic pathways are now thought to contribute to a number of human diseases, ranging from neurodegenerative disorders to malignancy ${ }^{32}$. A number of studies have revealed a high frequency of apoptosis in spontaneously regressing tumors and in tumors treated with cytotoxic anticancer agents ${ }^{33}$. There is a premise that anticancer agents induce apoptotic cell death and this implies that cellular responses occurring after the drug-target interaction can have impact on drug-induced cell death ${ }^{34}$.

Sanguinarine-mediated apoptosis (Fig. 2) has been found in human epidermoid carcinoma (A 431 ${ }^{24}$, human prostate cancer (LNCaP, DU-145, PC-3) (ref. ${ }^{22,35}$ ) and breast cancer $(\mathrm{MCF}-7)^{36,37}$ cell lines, human endocervical (HeLa) $\left(\right.$ ref. $\left.^{38}\right)$, human melanoma (M4Beu), human colon adenocarcinoma (DLD-1), lung non-smallcell carcinoma (A 549) $\left(\right.$ ref. $^{36}$ ), human uveal melanoma (OCM-1) (ref. ${ }^{39}$ ), histiocytic lymphoma (U 937), myeloid leukemia (ML-1a) $\left(\right.$ ref. $\left.^{40}\right)$, human erythroleukemia (K 562, JM1) (ref. ${ }^{40-42}$ ) cell lines, immortalized human keratinocytes (HaCaT) $\left(\right.$ ref. $\left.^{25}\right)$ and human primary 

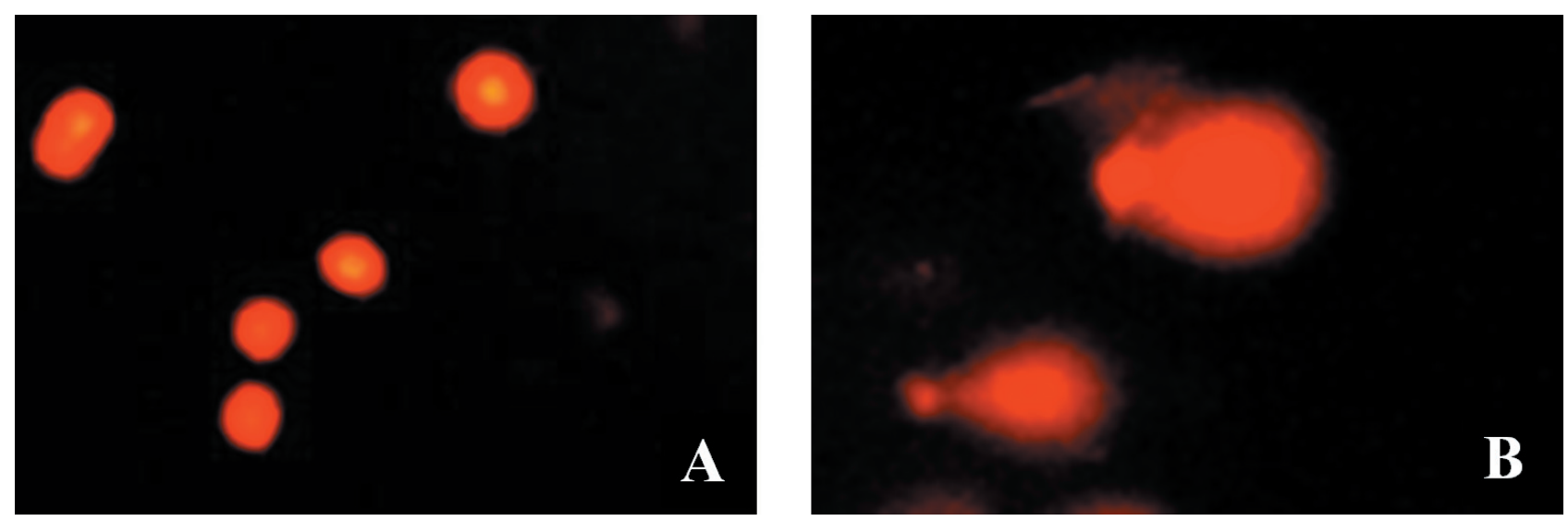

Fig. 1. DNA damage (single strand breaks) of gingival fibroblasts evaluated by Comet assay. (A) untreated control cells; (B) cells treated with SA $(1 \mu \mathrm{M})$ for $6 \mathrm{~h}^{11}$.
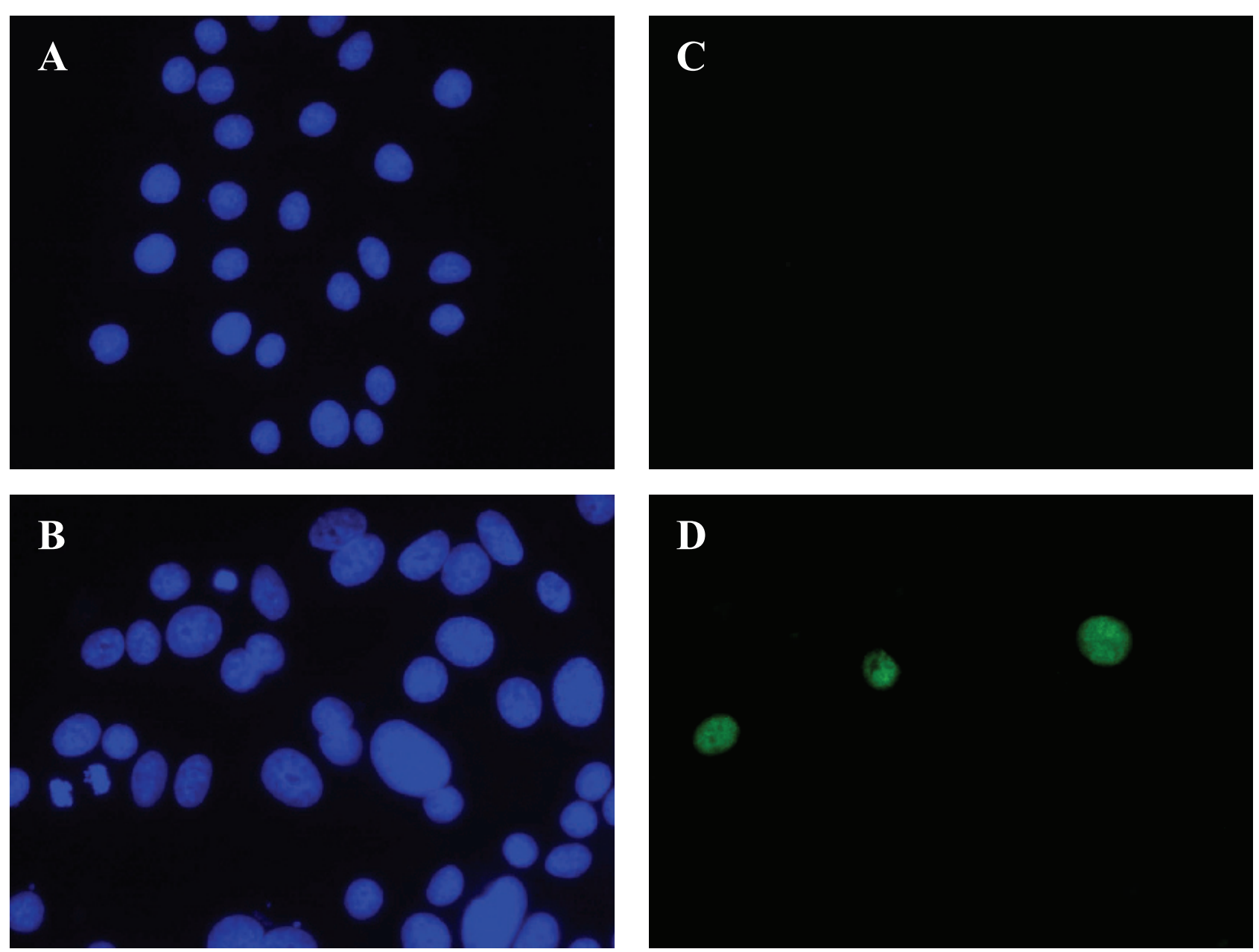

Fig. 2. Detection of apoptotic cells evaluated by the TUNEL assay in the prostate cancer (DU-145) cell line. (A) untreated control cells (DAPI); (B) cells treated with SA $(2.25 \mu \mathrm{M})$, (DAPI); (C) untreated control cells (TUNEL); (D) cells treated with SA $(2.25 \mu \mathrm{M})$ (TUNEL) $\left(\right.$ ref. $\left.^{11}\right)$.

fibroblasts ${ }^{36}$. Chelerythrine-mediated apoptosis has been determined in human breast cancer (MCF-7) (ref. ${ }^{43}$ ), human uveal melanoma (OCM-1) (ref. ${ }^{39}$ ), human neuroblastoma (SH-SY5Y), and colon carcinoma (HCT116) ${ }^{43}$ cell lines and neonatal rat cardiac myocytes ${ }^{44}$.

\section{SA/CHE-mediated activation of caspase-3}

and depletion of $G S H$

The caspase-cascade system plays a vital role in the induction, transduction and amplification of intracellular apoptotic signals. Caspases, closely associated with apoptosis, are aspartate-specific cysteine proteases and members of the interleukin-1 $\beta$-converting enzyme family. 


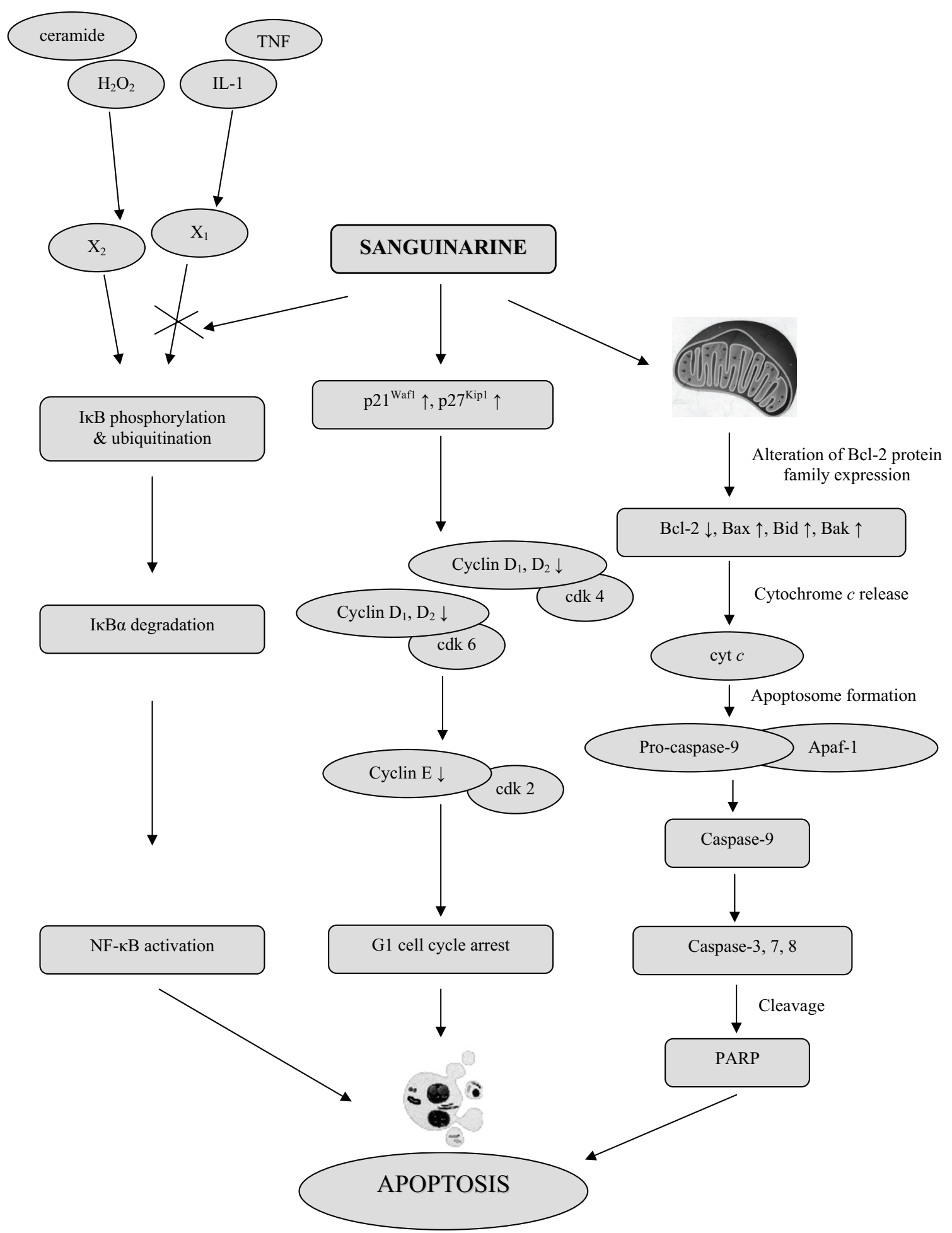

Fig. 3. The proposed model for sanguinarine-mediated apoptosis via three different pathways: i) activation of $\mathrm{NF}^{\mathrm{B}} \mathrm{B}^{57}$; ii) cell cycle arrest ${ }^{22}$; iii) the mitochondrial damage ${ }^{25}$.

The activation and function of caspases, involved in the delicate caspase-cascade system, are regulated by various kinds of molecules, such as the inhibitor of apoptosis protein, Bcl-2 family proteins, $\mathrm{Ca}^{2+}$, and calpain ${ }^{45}$. Generally, there are two pathways through which the caspase family proteases can be activated: (i) one is the death signalinduced, death receptor-mediated pathway; (ii) the other is the stress-induced, mitochondrion-mediated pathway. Not all caspases are involved in apoptosis. The caspases that have been well described are caspase- $3,-6,-7,-8$, and caspase-9 $\left(\right.$ ref. $\left.^{46,47}\right)$. Caspase- 3 is a key factor in apoptosis execution. The proactive form, procaspase-3, can be activated by caspase- $3,-8,-9,-10$, cysteine protease protein of molecular mass $32 \mathrm{kDa}$ (CPP32), granzyme B (Gran B), 
and others. The downstream substrates of caspase-3 include procaspase-3, procaspase-6, procaspase-9, DNAprotein kinase (DNA-PK), protein kinase C $(\mathrm{PKC} \gamma)$, poly(ADP-ribose) polymerase (PARP), D4-GDP-dissociation inhibitor for Rho family GTPases (D4-GDI), and various components of the cytoskeleton. The mitochondrial damage causes the release of cytochrome $c$ and activation of Apaf-1 and thereby initiating activation of the caspase machinery that, in fact, is believed to be the execution phase of apoptosis ${ }^{48}$.

SA treatment $(0.1,0.25,0.5,1$ and $2 \mu \mathrm{M})$ was found to result in increased levels of cytochrome $c$ and Apaf-1 and in a significant increase in the active form of caspase-3, caspase-7, caspase-8, and caspase- 9 in a dose-dependent manner in human immortalized HaCaT keratinocytes ${ }^{25}$. This process was accompanied by cleavage of the caspase3 substrate PARP and subsequent DNA degradation and apoptotic death. These results clearly suggest the role of mitochondrial events in SA-mediated apoptosis of $\mathrm{HaCaT}$ keratinocytes. Treatment with SA $(2.1 \mu \mathrm{M}$ and $4.2 \mu \mathrm{M})$ for $4 \mathrm{~h}$ induced apoptosis displayed by cell surface blebbing and caspase- 3 activation was confirmed by induction of proteolytic cleavage of PARP in human papillomavirus (HPV) type 16-immortalized endocervical cells ${ }^{38}$. On the other hand, concentrations of SA $(8.5 \mu \mathrm{M}$ and $16.9 \mu \mathrm{M})$ caused oncosis characterized by cell swelling, vacuolation, enhanced permeabilization of cytoplasmatic membrane and inactivation of caspase- 3 (ref. ${ }^{38}$ ). A similar effect of both alkaloids, SA and $\mathrm{CHE}$, was found on a primary human uveal melanoma OCM-1 cell line ${ }^{39}$. At lower concentrations (2.7 and $10 \mu \mathrm{M}$ ) of SA or CHE, apoptosis was found in the cells, whereas for higher doses of alkaloids $(20 \mu \mathrm{M})$ necrosis was the dominant form of cell death. SA treatment $\left(\mathrm{IC}_{50} 0.9-3.3 \mu \mathrm{M}\right)$ notably inhibited the growth of human melanoma M4Beu, breast cancer MCF-7 and prostate cancer PC-3 cell lines without difference in cytotoxicity against normal human fibroblasts and cancer cells ${ }^{36}$. This effect was related to a rapid apoptotic response subsequent to GSH depletion and caspase-3/7 activation. SA-mediated caspase-3 activation was also seen in a human erythroleukemia K 562 cell line in the apoptosis-inducing concentration $(4 \mu \mathrm{M})\left(\right.$ ref. $\left.{ }^{41}\right)$.

\section{SA-induced targeting of Bcl-2 protein family}

Members of the Bcl-2 protein family regulate and execute many cell intrinsic apoptotic pathways, including those arising from dysregulated expression of cellular oncogenes. The Bcl-2 family members can be divided into three subfamilies classified according to their content of Bcl-2 homology (BH) domains: (i) the anti-apoptotic members (Bcl-2, Bcl-X ${ }_{L}, \mathrm{Mcl}-1, \mathrm{Bcl}-1-\mathrm{w}, \mathrm{Ced}-9$, etc.) share all four BH domains; (ii) the multi-BH domain pro-apoptotic members (Bax, Bak, Bok, Bcl- $\mathrm{X}_{\mathrm{S}}$ ) contain BH1-3 domains; (iii) a diverse group of loosely related pro-apoptotic proteins (Bid, Bik, Bad, Bim, PUMA, NOXA, etc.) only have a $\mathrm{BH} 3$ domain.

In human leukaemia JM1 and K 562 cell lines SAinduced apoptosis with classic morphologic changes was observed at low concentrations $(4 \mu \mathrm{M})$ and cell death comparable to oncosis was found at high concentrations $(34 \mu \mathrm{M})\left(\right.$ ref. $\left.^{40}\right)$. SA-treated K 562 cells showed a significant increase in expression of the pro-apoptotic Bax protein during apoptosis. It has been reported that SA probably targets a very efficient up-stream Bax activation system $^{40}$. Treatment of human neuroblastoma SH-SY5Y cells with $\mathrm{CHE}(2.5$ and $5 \mu \mathrm{M})$ for $16 \mathrm{~h}$ induced a substantial decrease in mitochondrial membrane potential and triggered apoptosis through a mechanism involving direct targeting of Bcl-2 family proteins ${ }^{43}$. CHE was found to act as an antagonist to the anti-apoptotic protein Bcl$\mathrm{X}_{\mathrm{L}}$ (ref. ${ }^{43}$ ) and to inhibit protein kinase $\mathrm{C}$ (ref. ${ }^{49}$ ). Both $\mathrm{SA}$ and $\mathrm{CHE}$ were also shown to inhibit anti-apoptotic mitogen-activated protein kinase phosphatase ${ }^{50}$. The effect of SA treatment (0.1-2 $\mu \mathrm{M}$ for $24 \mathrm{~h}$ ) was also evaluated on the levels of Bax and Bcl-2 protein expression in immortalized human keratinocytes (HaCaT) $\left(\right.$ ref. $\left.^{25}\right)$. SA treatment of HaCaT keratinocytes resulted in significant decrease in the levels of anti-apoptotic $\mathrm{Bcl}-2$ protein and a dose-dependent increase in the pro-apoptotic Bax protein. SA caused apoptotic death of HaCaT cells by the release of cytochrome $\mathrm{c}$ from mitochondria into the cytosol and the activation of Apaf-1 in the cytosol.

\section{SA-mediated alterations in cell cycle}

Cell-cycle progression relies on activation of cyclins and cyclin-dependent kinases (CDKs), which successively act together in G1 to initiate the $S$ phase and in $G 2$ to initiate mitosis. To prevent abnormal proliferation, cyclinCDK complexes are precisely regulated by two families of cell cycle inhibitors that block their catalytic activity ${ }^{51}$. Since uncontrolled cyclin-dependent kinase activity is often the cause of human cancer, their function is tightly regulated by cell-cycle inhibitors such as the $\mathrm{p} 21^{\text {Waf } 1 / \text { Cip } 1}$ and $\mathrm{p} 27^{\mathrm{Kip} 1}$ proteins. Following anti-mitogenic signals or DNA damage, $\mathrm{p} 21^{\mathrm{Waf} / \mathrm{Cip} 1}$ and $\mathrm{p} 27^{\mathrm{Kip} 1}$ bind to cyclin-CDK complexes to inhibit their catalytic activity and induce cell-cycle arrest ${ }^{52}$. Adhami et al. ${ }^{22}$ focused on the antiproliferative effects of SA on growth/proliferation of human prostate cancer cells and the involvement of cell cycle regulatory events as the mechanism of this response. SA treatment $(0.2-2 \mu \mathrm{M}$ for $24 \mathrm{~h})$ in both cancer cell lines resulted in (i) significant induction of CDK inhibitors $\mathrm{p} 21^{\mathrm{Waf} 1 / \mathrm{Cip} 1}$ and $\mathrm{p} 27^{\mathrm{Kip} 1}$ in total levels; (ii) down-regulation of cyclin $\mathrm{D}_{1}, \mathrm{D}_{2}$ and $\mathrm{E}$; (iii) and down-regulation of $\mathrm{CDK}$ 2,4 , and 6. SA imparted cell cycle dysregulation in both androgen-sensitive (LNCaP) and androgen-insensitive (DU-145) human prostate carcinoma cells via up-regulation of CDK inhibitors involved in $\mathrm{G} 0 / \mathrm{G} 1$ progression of cell cycle. The authors found that SA caused cell cycle blockade and apoptosis of prostate cancer cells irrespective of their androgen status.

Holy et al. ${ }^{37}$ investigated the responses of cell cycle regulatory molecules to SA $(5-10 \mu \mathrm{M})$, using immunocytochemical methods that visualized cyclin $\mathrm{D}_{1}$ and topoisomerase II behavior in MCF-7 breast cancer cell line. SA-mediated cellular events resulted in extended cell cycle arrest in G0/G1 and inhibition of cell proliferation. The growth inhibition was accompanied by a striking re- 
localization of cyclin $\mathrm{D}_{1}$ and topoisomerase II from the nucleus to the cytoplasm. SA was incorporated by cells and concentrated in the nucleus within minutes, where it rapidly inhibited DNA synthesis. This model suggested that SA may help suppress malignant cell growth at subapoptotic concentrations.

Recent study analyzed the antiproliferative activity of $\mathrm{SA}$ in relation to its effects on mitosis and microtubule assembly. SA did not cause the arrest of cell cycle progression at mitosis but it induced aggregation of tubulin in the presence of microtubule-associated proteins. The binding of SA to tubulin induced conformational changes in tubulin ${ }^{53}$. One of the major obstacles to effective drug action is the efflux of drugs after their entry into cells by protein pumps such as P-glycoprotein and multiple resistance protein $1\left(\right.$ ref. $\left.^{54}\right)$. As SA binds tightly to tubulin, it may be difficult for the efflux machinery to pump out drugs. Thus, the tight binding of SA to tubulin may be beneficial in cancer chemotherapy ${ }^{53}$.

\section{SA-mediated activation of $N F-\kappa B$}

$\mathrm{NF}-\kappa \mathrm{B}$ is a nuclear transcription factor that regulates expression of a large number of genes involved in the regulation of apoptosis, tumorigenesis, inflammation, atherosclerosis, viral replication and many autoimmune diseases ${ }^{55}$. NF- $\mathrm{kB}$ is activated by a variety of stimuli that include cytokines, their receptors, growth factors, cell adhesion proteins, lymphokines, radiation, pharmacologic agents, and stress. In its inactive form, NF- $\mathrm{kB}$ is sequestered in the cytoplasm, bound inhibitor proteins of the I $\mathrm{B}$ family. The various stimuli that activate NF- $\kappa \mathrm{B}$ cause phosphorylation of $\mathrm{I} \kappa \mathrm{B}$, which is followed by its ubiquinitation and degradation. This results in exposure of the nuclear localization signals on NF-kB subunits and the subsequent translocation of the molecule to the nucleus. In the nucleus, NF- $\mathrm{B}$ B binds with the consensus sequence of various genes and thus activates their transcription ${ }^{56}$.

SA has been found to be a potential candidate for intervening in NF-kB-dependent pathological responses ${ }^{57}$. Treatment of human myeloid ML-1a cells with tumor necrosis factor rapidly activated NF- $\mathrm{KB}$ and this activation was completely suppressed by SA in a dose- and time-dependent manner. SA did not inhibit the binding of NF- $\mathrm{KB}$ protein to the DNA but inhibited the pathway leading to NF- $\kappa \mathrm{B}$ activation. Chelerythrine had no effect on NF- $\mathrm{NB}$ activation

\section{CHE-/SA-mediated apoptosis induced by generation of reactive oxygen species}

Reactive oxygen species (ROS) production is known to play an essential role in mediating cytochrome c release and subsequent apoptosis in cardiac myocytes ${ }^{58}$. It was demonstrated that antioxidant $\mathrm{N}$-acetyl-L-cysteine (NAC) could significantly inhibit the release of cytochrome $c$.

Yamamoto et al. investigated that $\mathrm{CHE}$, inhibitor of PKC, rapidly and potently induced cell death in neonatal rat cardiac myocytes ${ }^{44}$. It was found that generation of ROS rather than inhibition of PKC critically mediated CHE-induced rapid myocyte apoptosis. Cardiac myocyte death by $\mathrm{CHE}$ at 6-30 $\mu \mathrm{M}$ was accompanied by many characteristic findings of apoptosis, including pyknosis and cell shrinkage, posphatidyl serine externalization and activation of caspases. Another unique aspect of CHEinduced cell death was the fact that the morphological changes and myocyte death were strictly concentration-dependent. Typical cardiac myocyte apoptosis was induced at concentrations within a narrow range (between 6 and $30 \mu \mathrm{M}$ ), which was commonly used to block activities of PKC in cardiac myocytes. CHE caused cytochrome $c$ release from mitochondria and this was significantly inhibited in the presence of NAC, suggesting that ROS mediate $\mathrm{CHE}$-induced cytochrome $c$ release. CHE induced cardiac myocyte apoptosis more rapidly than exogenously applied $\mathrm{H}_{2} \mathrm{O}_{2}$. These results suggest that $\mathrm{CHE}$ rapidly induced cardiac myocyte apoptosis and that ROS production, possibly $\mathrm{H}_{2} \mathrm{O}_{2}$, and subsequent cytochrome $c$ release from mitochondria play an important role in mediating $\mathrm{CHE}$-induced rapid cardiac myocyte apoptosis. $\mathrm{CHE}$ was shown to be a useful positive control for determination of cardiac myocyte apoptosis and a model for explaining the signalling mechanism including potent apoptosis in cardiac myocytes ${ }^{44}$.

It has been reported that SA induced apoptosis which depends on the production of nitric oxide (NO) and superoxide radicals in prostate cancer cells ${ }^{35}$. This study was focused on cyclooxygenase-2 (COX-2) expression which may rescue prostate cancer cells from SA-induced apoptosis by a mechanism involving inhibition of NO synthase (NOS) activity. These findings support the suggestion that coadministration of COX-2 inhibitors with SA may be developed as a strategy in the management of prostate cancer $^{35}$.

\section{CONCLUSION}

Successful resolution to the design of agents that effectively induce tumor regression lies, at least in part, in overcoming the inherent resistance in many transformed cells to undergo apoptosis. Owing to their apoptotic potential these alkaloids are hypothesized to be not only good candidates for chemotherapeutic regimens, but may also contribute to the development of successful immune therapies of some carcinomas. SA itself or some of its derivatives might be good candidates as pro-apoptotic drugs for cancer therapy. However, the complete signalling cascade by which SA and/or CHE treatment induces apoptotic cell death is not yet elucidated. Overall, the results of recent studies suggest that SA and $\mathrm{CHE}$ could be developed as agents in the management of cancer.

\section{ACKNOWLEDGMENT}

This research is supported by the Ministry of Education of the Czech Republic (MSM 6198959216). 


\section{REFERENCES}

1. Zdarilova A, Malikova J, Dvorak Z, Ulrichova J, Simanek V. (2006) Quaternary isoquinoline alkaloids sanguinarine and chelerythrine. In vitro and in vivo effects. Chem. Listy 100, 30-41.

2. Walterova D, Ulrichova J, Valka I, Vicar J, Vavreckova C, Taborska E, Harjrader RJ, Meyer DL, Cerna H, Simanek V. (1995) Benzo[c]phenanthridine alkaloids sanguinarine and chelerythrine: biological activities and dental care applications. Acta Univ Palacki Olomuc Fac Med 139, 7-16.

3. Slaninova I, Taborska E, Bochorakova H, Slanina J. (2001) Interaction of benzo[c]phenanthridine and protoberberine alkaloids with animal and yeast cells. Cell Biol Toxicol 17, 51-63.

4. Walterova D, Ulrichova, Preininger V, Simanek V, Lenfeld J, Lasovsky J. (1981) Inhibition of liver alanine aminotransferase activity by some benzophenanthridine alkaloids. J Med Chem 24 , 1100-1103.

5. Bartak P, Vlckova M, Ulrichova J, Simanek V, Vespalec R. (2003) Interactions of sanguinarine and chelerythrine with molecules containing the mercapto group. J Phys Org Chem 16, 803-810.

6. Ulrichova J, Dvorak Z, Vicar J, Lata J, Smrzova J, Sedo A, Simanek V. (2001) Cytotoxicity of natural compounds in hepatocyte cell culture models. The case of quaternary benzo[c]phenanthridine alkaloids. Toxicol Lett 125, 125-132.

7. Stiborova M, Simanek V, Frei E, Hobza P, Ulrichova J. (2002) DNA adduct formation from quaternary benzo[c]phenanthridine alkaloids sanguinarine and chelerythrine as revealed by the P-32postlabeling technique. Chem Biol Interact 140, 231-242.

8. Faddeeva MD, Beliaeva TN. (1997) [Sanguinarine and ellipticine cytotoxic alkaloids isolated from well-known antitumor plants. Intracellular targets of their action]. Tsitologiia 39, 181-208.

9. Das M, Khanna SK. (1997) Clinicoepidemiological, toxicological, and safety evaluation studies on argemone oil. Crit Rev Toxicol 27, 273-297.

10. Simanek V, Vespalec R, Sedo A., Ulrichova J, Vicar J. (2003) Quaternary benzo[c]phenanthridine alkaloids - Biological activities. Chemical Probes in Biology. NATO Science Series 129, 145154.

11. Malikova J, Zdarilova A, Hlobilkova A, Ulrichova J. (2006) Effects of quaternary benzo $[c]$ phenanthridine alkaloids on human normal versus cancer cells., unpublished results.

12. Das M, Ansari KM, Dhawan A, Shukla Y, Khanna SK. (2005) Correlation of DNA damage in epidemic dropsy patients to carcinogenic potential of argemone oil and isolated sanguinarine alkaloid in mice. Int J Cancer 117, 709-717.

13. Ansari KM, Dhawan A, Khanna SK, Das M. (2005) In vivo DNA damaging potential of sanguinarine alkaloid, isolated from argemone oil, using alkaline Comet assay in mice. Food Chem Toxicol 43 , 147-153.

14. Ansari KM, Dhawan A, Khanna SK, Das M. (2006) Protective effect of bioantioxidants on argemone oil/sanguinarine alkaloid induced genotoxicity in mice. Cancer Lett, Feb 1; [Epub ahead of print].

15. Hakim SA, Mijovic V, Walker J. (1961) Experimental transmission of sanguinarine in milk: detection of a metabolic product. Nature 189, 201-204.

16. Tandon S, Das M, Khanna SK. (1993) Biometabolic elimination and organ retention profile of argemone alkaloid, sanguinarine, in rats and guinea pigs. Drug Metab Dispos 21, 194-197.

17. Psotova J, Klejdus B, Vecera R, Kosina P, Kuban V, Vicar J, Simanek V, Ulrichova J. (2006) A liquid chromatographic-mass spectrometric evidence of dihydrosanguinarine as a first metabolite of sanguinarine transformation in rat. J Chromatogr B Analyt Technol Biomed Life Sci 830, 165-172.

18. Weiss D, Baumert A, Vogel M, Roos W. (2006) Sanguinarine reductase, a key enzyme of benzophenanthridine detoxification. Plant Cell Environ 29, 291-302

19. Hodgson E, Levi PE. (1994) Introduction to biochemical toxicology. Appelton\&Lange, Norwalk. 219-240.

20. Vecera R, Klejdus B, Kosina P, Orolin J, Stiborova M, Smrcek S, Vicar J, Dvorak Z, Ulrichova J, Kuban V, Anzenbacher P, Simanek
V. (2006) Disposition of sanguinarine in rat. Drug Metab Dispos, accepted.

21. Belyaeva T, Leontieva E, Shpakov A, Mozhenok T, Faddejeva M. (2003) Sensitivity of lysosomal enzymes to the plant alkaloid sanguinarine: comparison with other SH-specific agents. Cell Biol Int 27, 887-895.

22. Adhami VM, Aziz MH, Reagan-Shaw SR, Nihal M, Mukhtar H, Ahmad N. (2004) Sanguinarine causes cell cycle blockade and apoptosis of human prostate carcinoma cells via modulation of cyclin kinase inhibitor-cyclin-cyclin-dependent kinase machinery. Mol. Cancer Ther. 3, 933-940.

23. Chmura SJ, Dolan ME, Cha A, Mauceri HJ, Kufe DW, Weichselbaum RR. (2000) In vitro and in vivo activity of protein kinase $\mathrm{C}$ inhibitor chelerythrine chloride induces tumor cell toxicity and growth delay in vivo. Clin Cancer Res 6, 737-742.

24. Ahmad N, Gupta S, Husain MM, Heiskanen KM, Mukhtar H. (2000) Differential antiproliferative and apoptotic response of sanguinarine for cancer cells versus normal cells. Clin Cancer Res 6, 1524-1528.

25. Adhami VM, Aziz MH, Mukhtar H, Ahmad N. (2003) Activation of prodeath $\mathrm{Bcl}-2$ family proteins and mitochondrial apoptosis pathway by sanguinarine in immortalized human $\mathrm{HaCaT}$ keratinocytes. Clin Cancer Res 9, 3176-3182.

26. Kasibhatla S, Tseng B. (2003) Why target apoptosis in cancer treatment? Mol Cancer Ther 2, 573-580.

27. Wyllie AH. (1997) Apoptosis and carcinogenesis. Eur J Cell Biol $73,189-197$.

28. Orrenius S. (1995) Apoptosis: molecular mechanisms and implications for human disease. J Intern Med 237, 529-536.

29. McConkey DJ, Zhivotovsky B, Orrenius S. (1996) Apoptosis-molecular mechanisms and biomedical implications. Mol Aspects Med 17, 1-110.

30. Tapia-Vieyra JV, Mas-Oliva J. (2001) Apoptosis and cell death channels in prostate cancer. Arch Med Res 32, 175-185.

31. Collins JA, Schandi CA, Young KK, Vesely J, C. WM. (1997) Major DNA fragmentation is a late event in apoptosis. J Histochem Cytochem 45, 923-934.

32. Van Cruchten S, Van Den Broeck W. (2002) Morphological and biochemical aspects of apoptosis, oncosis and necrosis. Anat Histol Embryol 31, 214-223.

33. Lowe SW, Lin AW. (2000) Apoptosis in cancer. Carcinogenesis $21,485-495$.

34. Dive C, Hickman JA. (1991) Drug-target interactions: only the first step in the commitment to a programmed cell death? Br J Cancer 64, 192-196.

35. Huh J, Liepins A, Zielonka J, Andrekopoulos C, Kalyanaraman B, Sorokin A. (2006) Cyclooxygenase 2 rescues LNCaP prostate cancer cells from sanguinarine-induced apoptosis by a mechanism involving inhibition of nitric oxide synthase activity. Cancer Res 66, 3726-3736.

36. Debiton E, Madelmont JC, Legault J, Barthomeuf C. (2003) Sanguinarine-induced apoptosis is associated with an early and severe cellular glutathione depletion. Cancer Chemother. Pharmacol. $51,474-482$.

37. Holy J, Lamont G, Perkins E. (2006) Disruption of nucleocytoplasmic trafficking of cyclin D1 and topoisomerase II by sanguinarine. BMC Cell Biol 7, 13.

38. Ding ZH, Tang SC, Weerasinghe P, Yang XL, Pater A, Liepins A. (2002) The alkaloid sanguinarine is effective against multidrug resistance in human cervical cells via bimodal cell death. Biochem Pharmacol. 63, 1415-1421.

39. Kemeny-Beke A, Aradi J, Damjanovich J, Beck Z, Facsko A, Berta A, Bodnar A. (2005) Apoptotic response of uveal melanoma cells upon treatment with chelidonine, sanguinarine and chelerythrine. Cancer Lett. 237, 67-75.

40. Weerasinghe P, Hallock S, Tang SC, Liepins A. (2001) Role of Bcl2 family proteins and caspase- 3 in sanguinarine-induced bimodal cell death. Cell Biol Toxicol 17, 371-381.

41. Weerasinghe P, Hallock S, Tang SC, Liepins A. (2001) Sanguinarine induces bimodal cell death in K562 but not in high Bcl-2-expressing JM1 cells. Pathol Res Pract 197, 717-726. 
42. Weerasinghe P, Hallock S, Liepins A. (2001) Bax, Bcl-2, and NFkappa B expression in sanguinarine induced bimodal cell death. Exp Mol Pathol 71, 89-98.

43. Chan SL, Lee MC, Tan KO, Yang LK, Lee AS, Flotow H, Fu NY, Butler MS, Soejarto DD, Buss AD, Yu VC. (2003) Identification of chelerythrine as an inhibitor of BclXL function. J Biol Chem 278, 20453-20456.

44. Yamamoto S, Seta K, Morisco C, Vatner SF, Sadoshima J. (2001) Chelerythrine rapidly induces apoptosis through generation of reactive oxygen species in cardiac myocytes. J Mol Cell Cardiol 33, 1829-1848.

45. Launay S, Hermine O, Fontenay M, Kroemer G, Solary E, Garrido C. (2005) Vital functions for lethal caspases. Oncogene 24, 51375148 .

46. Thornberry NA, Lazebnik Y. (1998) Caspases: enemies within Science 281, 1312-1316.

47. Mancini M, Nicholson DW, Roy S, Thornberry NA, Peterson EP, Casciola-Rosen LA, Rosen A. (1998) The caspase-3 precursor has a cytosolic and mitochondrial distribution: implications for apoptotic signaling. J Cell Biol. 140, 1485-1495.

48. Hajra KM, Liu JR. (2004) Apoptosome dysfunction in human cancer. Apoptosis 9, 691-704

49. Herbert JM, Augereau JM, Gleye J, Maffrand JP. (1990) Chelerythrine is a potent and specific inhibitor of protein kinase C. Biochem Biophys Res Commun 172, 993-999.
50. Vogt A, Tamewitz A, Skoko J, Sikorski RP, Giuliano KA, Lazo JS. (2005) The benzo[c] phenanthridine alkaloid, sanguinarine, is a selective, cell-active inhibitor of mitogen-activated protein kinase phosphatase-1. J Biol Chem 280, 19078-19086.

51. Sherr CJ, Roberts JM. (1999) CDK inhibitors: positive and negative regulators of G1-phase progression. Genes Dev 13, 1501-1512.

52. Coqueret O. (2003) New roles for p21 and p27 cell-cycle inhibitors: a function for each cell compartment? Trends Cell Biol 13, 65-70.

53. Lopus M, Panda D. (2006) The benzophenanthridine alkaloid sanguinarine perturbs microtubule assembly dynamics through tubulin binding. Febs J 273, 2139-2150.

54. Legrand O, Simonin G, Perrot JY, Zittoun R, Marie JP. (1998) Pgp and MRP activities using calcein-AM are prognostic factors in adult acute myeloid leukemia patients. Blood 91, 4480-4488.

55. Maldonado V, Melendez-Zajgla J, Ortega A. (1997) Modulation of NF-kappa B, and Bcl-2 in apoptosis induced by cisplatin in HeLa cells. Mutat Res 381, 67-75.

56. Baldwin AS, Jr. (1996) The NF-kappa B and I kappa B proteins: new discoveries and insights. Annu Rev Immunol 14, 649-683.

57. Chaturvedi MM, Kumar A, Darnay BG, Chainy GBN, Agarwal S, Aggarwal BB. (1997) Sanguinarine (pseudochelerythrine) is a potent inhibitor of NF-kappa B activation, I kappa B alpha phosphorylation, and degradation. J Biol Chem 272, 30129-30134.

58. von Harsdorf R., Li PF, Dietz R. (1999) Signaling pathways in reactive oxygen species-induced cardiomyocyte apoptosis. Circulation. 99, 2934-2941. 